\title{
Phase transitions and their effects on the thermal diffusivity behaviour of some $\mathrm{SiO}_{2}$ polymorphs
}

\section{(Transições de fase e seus efeitos no comportamento da difusividade térmica de alguns polimorfos do $\mathrm{SiO}_{2}$ )}

\author{
J. B. Baldo, W. N. dos Santos \\ Department of Materials Engineering \\ Federal University of $S$. Carlos \\ Rod. Washington Luiz, km 235, C.P. 676, 13565-905, S. Carlos, SP. Brazil \\ dwns@power.ufscar.br
}

\begin{abstract}
Thermal diffusivity is a material physical property important in all problems involving non-steady state heat transfer calculations, being a decisive parameter in the response of materials subjected to thermal shock. In this work it is presented a fundamental study related to how the phase transitions may influence the thermal diffusivity behaviour as a function of temperature in the phase transforming $\mathrm{SiO}_{2}$. The experimental technique employed was the flash thermal diffusivity technique, and measurements were carried out from $100{ }^{\circ} \mathrm{C}$ up to approximately $1200^{\circ} \mathrm{C}$. It was found a strong dependence on the thermal diffusivity with the high and low temperature forms of the quartz and cristobalite phases.
\end{abstract}

Keywords: sintering, defects, thermal expansion, thermal properties, clays, refractories.

\section{Resumo}

A difusividade térmica é uma propriedade física do material importante em todos os problemas envolvendo cálculos de transferência de calor no estado não estacionário, sendo um parâmetro decisivo na resposta de materiais sujeitos a choques térmicos. Neste trabalho é feito um estudo relacionando a influência das transições de fase no comportamento da difusividade térmica em função da temperatura, nas transformações de fase do $\mathrm{SiO}_{2}$. A técnica experimental empregada foi a técnica de pulso de energia, e as medidas foram feitas desde $100^{\circ} \mathrm{C}$ até aproximadamente $1200^{\circ} \mathrm{C}$. Verificou-se uma forte dependência da difusividade térmica com as formas em alta e baixa temperaturas das fases quartzo e cristobalita. Palavras-chave: sinterização, defeitos, expansão térmica, propriedades térmicas, argilas, refratários.

\section{INTRODUCTION}

Modelling heat transfer under steady state or transient conditions is of fundamental importance in engineering design as well as the tailoring of thermal and mechanical behaviour of materials.

Physically, the thermal diffusivity expresses how fast heat propagates across a bulk material, being an important variable in transient heat transfer conditions.

On an atomic scale, heat transfer velocity has to do with how free phonons (heat transport carriers) may be generated and wander between arrangements of atoms (ions). If atoms (ions) were perfect harmonic oscillators, then each phonon would be able to transfer energy without any perturbation, presenting an apparent infinite mean free path, and as a result the thermal diffusivity would be infinitely large [1].

In practice, this happens not to be the case, considering defects are a condition for thermodynamic stability, which establishes a finite value for the phonon mean free path, before its scattering (Umklapp). From the previous point of view, the symmetry of atomic arrangements and the degree of openness of the atomic arrangement may influence phonon mean free path in addition to the temperature effects as shown in equation $\mathrm{A}, \mathrm{B}$ and $\mathrm{C}$, which are applicable to crystalline solids $[1,2]$.

$$
\begin{aligned}
& \mathrm{a}=\mathrm{k} / \rho \mathrm{c}_{\mathrm{p}} \\
& \mathrm{k}=\frac{1}{3} \rho \mathrm{c}_{\mathrm{p}} \mathrm{v} \lambda \\
& \lambda=\frac{20 \mathrm{~T}_{\mathrm{m}} \mathrm{d}}{\gamma^{2} \mathrm{~T}}
\end{aligned}
$$

where $\mathrm{a}=$ thermal diffusivity, $\mathrm{k}=$ thermal conductivity, $\rho=$ bulk density, $\mathrm{c}_{\mathrm{p}}=$ specific heat, $\mathrm{v}=$ phonon velocity, $\lambda=$ phonon mean free path, $\mathrm{T}_{\mathrm{m}}=$ melting point of the solid, $\mathrm{d}=$ lattice 
mean dimension, $\gamma=$ Gruneisen constant, $\mathrm{T}=$ absolute temperature, $\beta=$ compressibility modulus, $\Omega=$ molar volume, $\alpha=$ linear thermal expansion coefficient, $\mathrm{c}_{\mathrm{v}}=$ molar heat capacity.

Moreover the number of phonons generated as a function of temperature is given by:

$$
\mathrm{N}=\exp \left[1-\left(\frac{\mathrm{h} \omega}{2 \pi \kappa \mathrm{T}}\right)\right]
$$

where $\mathrm{h}=$ Planck's constant, $\omega=$ lattice oscillation frequency, $\kappa=$ Boltzmann constant and $\mathrm{T}=$ absolute temperature.

On a macro scale, thermal diffusivity and thermal conductivity are strongly dependent on the material microstructure characteristics.

Many ceramic materials present the so called polymorphism in which by means of displacive, reconstructive or martensitic reactions, phases change mineralogically in order to achieve the most thermodynamically stable arrangement for the temperature in question. In the case of silica the most common polymorphism occurs as shown below, and Table I shows their densities.

Pure $\mathrm{SiO}_{2}$ polymorphism:

$573{ }^{\circ} \mathrm{C}$

1) $\alpha$-quartz $\Leftrightarrow \beta$-quartz

$$
\Delta \mathrm{v}=1 \%
$$

$870{ }^{\circ} \mathrm{C}$

2) $\beta$-quartz $\Leftarrow \beta$-cristobalite

$\Delta \mathrm{v}=14 \%$

$1760{ }^{\circ} \mathrm{C}$

3) $\beta$-cristobalite $\Leftrightarrow$ silica glass,

where $\Delta v$ is the volumetric change of the specimen.

Impure $\mathrm{SiO}_{2}$ (containing $\mathrm{Fe}_{2} \mathrm{O}_{3}, \mathrm{~N}_{2} \mathrm{O}_{3}, \mathrm{CaO}$ ) polymorphism: $573{ }^{\circ} \mathrm{C}$

1) $\alpha$-quartz $\Leftarrow \beta$-quartz

$\Delta \mathrm{v}=1 \%$

$\mathrm{T}>1000{ }^{\circ} \mathrm{C} \quad \beta$-cristobalite

$\Delta \mathrm{v}=14 \%$

2) $\beta$-quartz $\Leftarrow \Rightarrow$

or

$\beta$-trydimite

(large grains)

(small grains the glassy phase saturates in $\mathrm{SiO}_{2}$ and reprecipitates in trydimite)

\section{$\mathrm{T}>1470{ }^{\circ} \mathrm{C} \quad \mathrm{T}>1710{ }^{\circ} \mathrm{C}$}

3) $\beta$-cristobalite $\Leftarrow \beta$-trydimite $\Leftarrow$ silica glass

In steps 2 and 3 the trydimite phase is originated from a process of solution-reprecipitation considering that the cristobalite in the periphery of original quartz particles dissolves
Table I - Polymorphs and their low and high temperature densities.

[Tabela I - Polímeros e suas densidades.]

\begin{tabular}{lc}
\hline Phases & $\begin{array}{c}\text { Density } \\
\left(\mathbf{k g} / \mathbf{m}^{3}\right)\end{array}$ \\
\hline$\alpha-$ quartz & 2650 \\
\hline$\beta$-quartz & 2530 \\
\hline$\alpha$-cristobalite & 2320 \\
\hline$\beta$-cristobalite & 2240 \\
\hline$\alpha-$ trydimite & 2280 \\
\hline$\beta$-trydimite & 2240 \\
\hline
\end{tabular}

in the liquid saturating it in $\mathrm{SiO}_{2}$ with subsequent reprecipitation as trydimite.

Another example of transformation, however not polymorphysm, with drastic microstructure changes is the one presented by kaolinitic clays when heated up to high temperatures $\left(>1000{ }^{\circ} \mathrm{C}\right)$. In the raw state, kaolinitic clays are mainly composed of two layered triclinic clay mineral kaolinite $\left(\mathrm{Si}_{2} \mathrm{O}_{5}\right)^{2-} \cdot\left(\mathrm{Al}_{2}(\mathrm{OH})_{4}\right)^{2+}$, plus accessory minerals including quartz, mica, feldspar, iron oxides and hydroxides, carbonates $(\mathrm{Ca}, \mathrm{Mg}$, $\mathrm{Fe}$ ) and organic matter. When the clay is heated up in the range from $450{ }^{\circ} \mathrm{C}$ to $600{ }^{\circ} \mathrm{C}$, the hydroxils of kaolinite are liberated in the form of water vapour, and with the collapse of the original triclinic cell (disorder in the $\mathrm{C}$ axis) acquires a virtual, but not complete, amorphous nature. This new phase is called metakaolinite which is composed of tiny particles leading to an extremely high surface area (> $400 \mathrm{~m}^{2} / \mathrm{g}$ ) and porosity [3].

On the range from $500{ }^{\circ} \mathrm{C}$ to $600{ }^{\circ} \mathrm{C}$ the accessory quartz present in the clay also transforms as shown before. On the range from $900{ }^{\circ} \mathrm{C}$ to $1000{ }^{\circ} \mathrm{C}$, mulite $\left(3 \mathrm{Al}_{2} \mathrm{O}_{3} .2 \mathrm{SiO}_{2}\right)$ starts an incipient crystallization which is completed at higher temperatures through growth by liquid phase, formed from the impurities of the clay material. Mullite is characterized by a relatively high number of oxygen vacancies which is responsible for its low thermal conductivity and thermal diffusivity.

In the case of silica, the high temperature polymorphism has a more symmetrical atomic arrangement despite being less dense. It is reasonable then to expect differences in the energy transport properties on each situation. Silica in the form of cristobalite and trydimite is an important refractory material for foundry, glass and siderurgy. In coke oven linings for instance, where silica bricks are massively used, it has been found that an increase of $20 \%$ in the material thermal conductivity results in $30 \%$ increase in coke output and lower emission of pollutants $\left(\mathrm{NO}_{\mathrm{x}}\right)$. In order to increase thermal conductivity of the bricks much effort have been devoted to increase the density by means of processing, additives, and or the use of high thermal conductivity second phase materials such as SiC.

Apparently no reports were made concerning specific effects on thermal properties due to the different phase transition mechanisms (displacive, reconstructive, or martensitic) on 
thermal diffusivity of ceramics.

The thermal diffusivity behavior of different $\mathrm{ZrO}_{2}$ phases were investigated, but the direct effect of phase transitions was not studied $[4,5]$. Based on this premise, in this work, it was investigated the direct effect of silica phase transitions specifically $\alpha \Leftarrow \beta$ quartz and $\alpha \Leftarrow \beta$ cristobalite on the thermal diffusivity behaviour as a function of temperature.

\section{SAMPLES PREPARATION}

Samples were shaped in discs format having $12 \mathrm{~mm}$ in diameter and thickness ranging from $1 \mathrm{~mm}$ to $2 \mathrm{~mm}$. The raw materials were $\alpha$-quartzite $\left(<2 \% \mathrm{Al}_{2} \mathrm{O}_{3}+\mathrm{TiO}_{2}+\mathrm{Fe}_{2} \mathrm{O}_{3}\right)$ for specimens of batch $\mathrm{A}$, and a plastic refractory clay, containing $32.34 \%$ alumina and $53.66 \%$ silica for specimens of batch B. Each raw material was thoroughly mixed in a polyethylene lined ball mill containing alumina grinding media, and then cold pressed at $50 \mathrm{MPa}$. In order to mineralise the quartz transitions into more stable phases, a lime milk solution, produced by the mixing of appropriate quantities of $\mathrm{Ca}(\mathrm{OH})_{2}$ and $\mathrm{Mg}(\mathrm{OH})_{2}$ which after decomposition would result in $2 \mathrm{wt} \%$ of $\mathrm{CaO}$ and $0.5 \mathrm{wt} \%$ percent of $\mathrm{MgO}$ were employed for sample batch A. Calcium lignsulfonate was employed as a binding agent for both $\mathrm{A}$ and $\mathrm{B}$ batches.

Set A ( 3 specimens) was fired in air at $1450{ }^{\circ} \mathrm{C}$ for $4 \mathrm{~h}$ and will be designated by A1450, and set B was also fired in air at
$1200{ }^{\circ} \mathrm{C}$ ( 3 specimens) and $1400{ }^{\circ} \mathrm{C}(3$ specimens $)$ for $2 \mathrm{~h}$, and will be respectively designated by B1200 and B1400. After firing, each composition was submitted to X-ray diffraction analysis.

\section{EXPERIMENTAL TECHNIQUE}

Thermal diffusivity measurements were carried out by using the flash thermal diffusivity technique [6]. In this technique a uniform heat pulse of short duration compared with the transient time through the sample is incident on the front face of a disc specimen, and the temperature raise on the rear face is recorded.

If no heat loss occurs, the normalized temperature increase on the rear face is given by

$$
\mathrm{V}=1+2 \sum_{\mathrm{n}=1}^{\infty}(-1)^{\mathrm{n}} \exp \left(-\mathrm{n}^{2} \omega^{2}\right)
$$

where $\omega=\pi^{2} \alpha \mathrm{t} / \mathrm{L}^{2}, \mathrm{~V}=\mathrm{T} / \mathrm{T}_{\mathrm{m}}=$ dimensionless temperature increase of the rear face, $\mathrm{T}=$ instantaneous temperature increase of the rear face of the specimen, $\mathrm{T}_{\mathrm{m}}=\mathrm{Q} / \rho \mathrm{c}_{\mathrm{p}} \mathrm{L}=$ maximum temperature increase of the rear face, $\mathrm{Q}=$ input energy on the front face, $\rho=$ density, $\mathrm{c}_{\mathrm{p}}=$ specific heat, and $\mathrm{L}=$ specimen length.

It is a common practice to employ the half maximum temperature raise time $t_{1 / 2}$ for which $\omega$ is equal to 1.38 , and hence the thermal diffusivity can be calculated using the

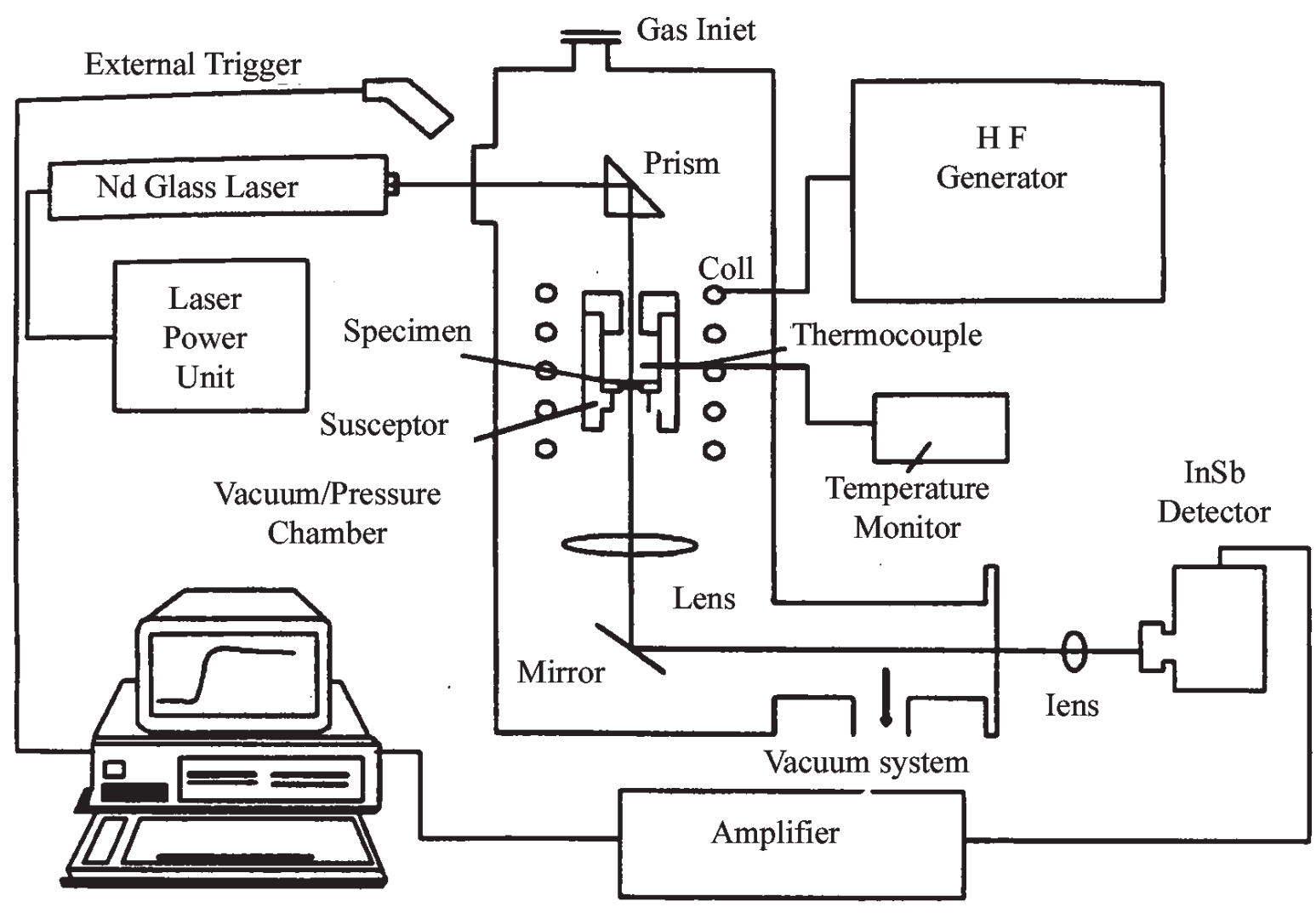

Micro Computer

Figure 1: Schematic of UMIST apparatus.

[Figura 1: Arranjo experimental da Universidade de Manchester/UMIST.] 


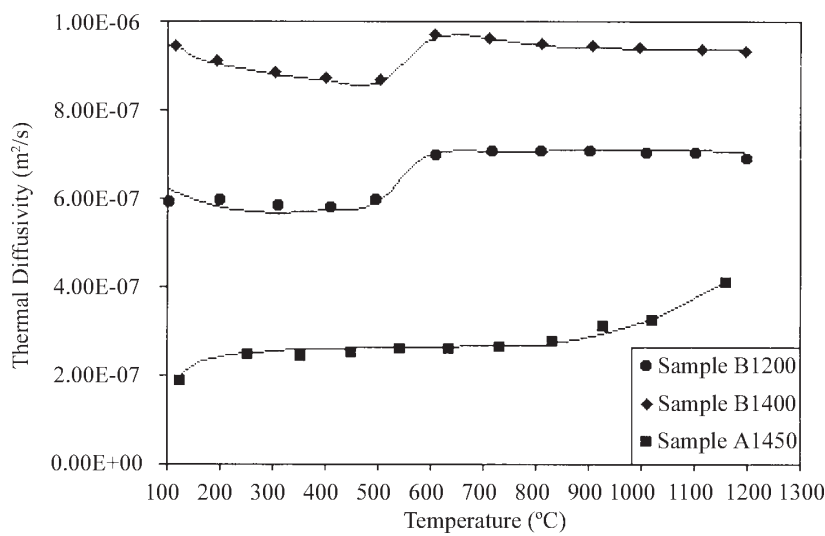

Figure 2: Thermal diffusivity as a function of temperature-heating branch.

[Figura 2: Difusividade térmica em função da temperaturaaquecimento.]

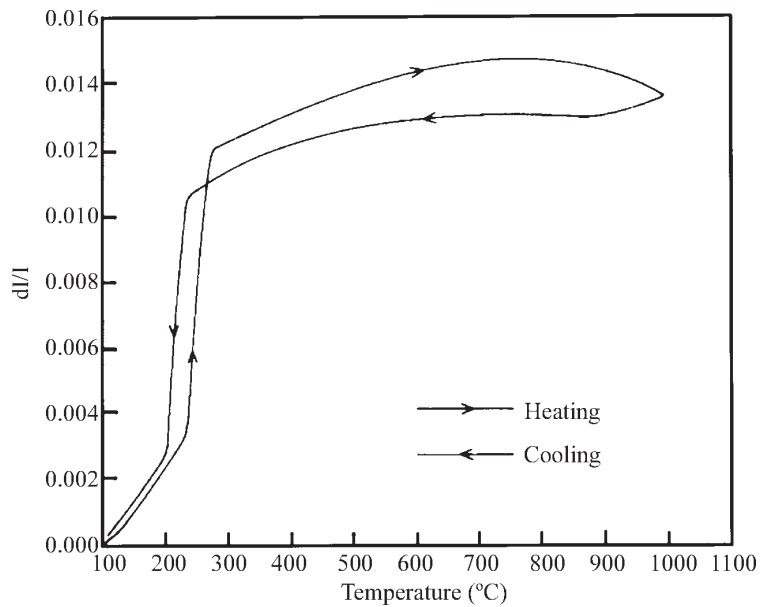

Figure 4: Fractional linear change as a function of temperature for sample A1450.

[Figura 4: Variação linear fracional em função da temperatura para a amostra A1450.]

following expression:

$$
\mathrm{a}=1.38 \mathrm{~L}^{2} / \pi^{2} \mathrm{t}_{1 / 2}
$$

Deviations from the idealized behaviour that have been addressed in the scientific literature are finite pulse time effects and heat losses. The former may be avoided by selecting a suitable sample size, but the latter are impossible to avoid at elevated temperatures. In the UMIST apparatus, developed by Taylor [7], the pulse profile has been determined and finite pulse time effects are corrected using the method developed by Clark and Taylor [8]:

$$
\mathrm{a}=\mathrm{C}_{1} \mathrm{~L}^{2} /\left(\mathrm{C}_{2} \mathrm{t}_{1 / 2}-l\right)
$$

where $\iota$ is the pulse dissipation time and $\mathrm{C}_{1}$ and $\mathrm{C}_{2}$ are constants whose values depend on the pulse shape. The heat losses are corrected using the method developed by Cowan [9].

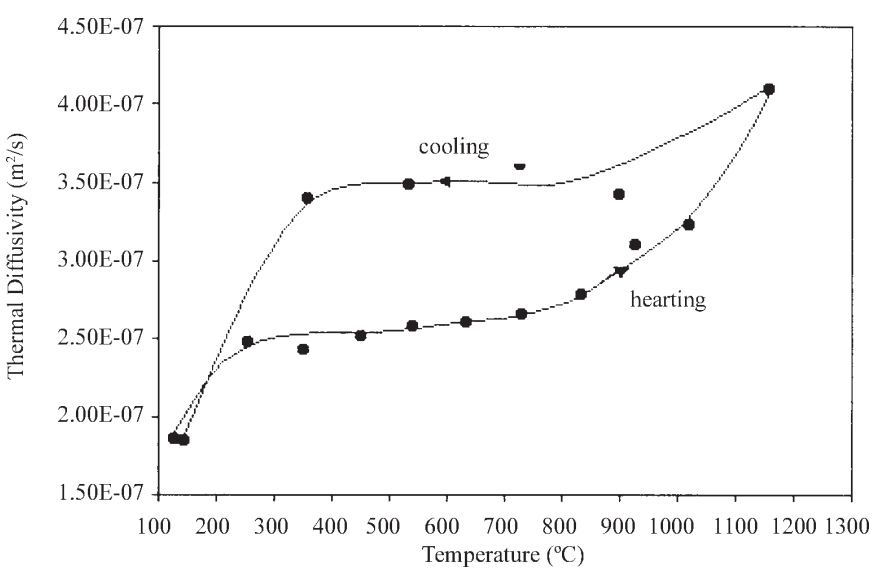

Figure 3: Thermal diffusivity as a function of temperature for sample A1450.

[Figura 3: Difusividade térmica em função da temperatura para a amostra A1450.]

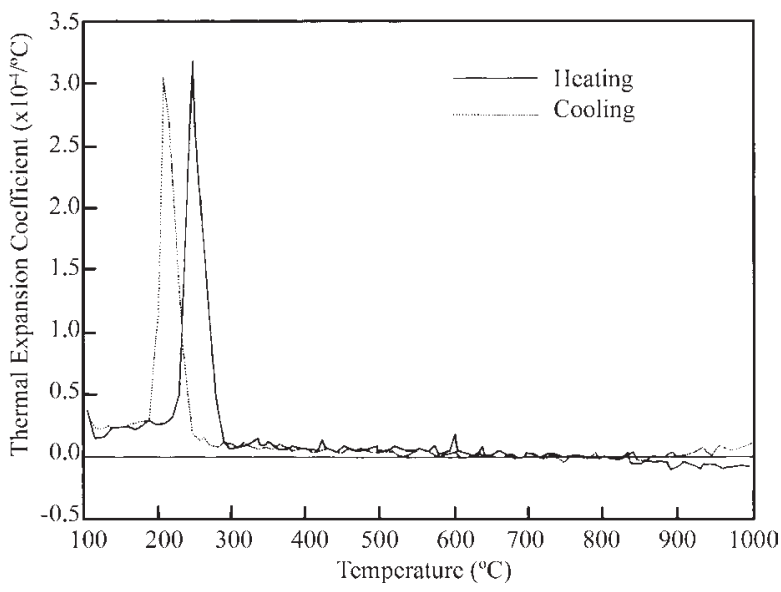

Figure 5: Thermal expansion coefficient as a function of temperature for sample A1450.

[Figura 5: Coeficiente de expansão térmica em função da temperatura para amostra A1450.]

The pulse source is a solid state Nd glass laser $(\lambda=1.067$ $\mu \mathrm{m})$ with a beam diameter of $16 \mathrm{~mm}$. The energy output is in the range 5-95 $\mathrm{J}$, and the pulse dissipation time is nominally $0.6 \mathrm{~ms}$. The disc shaped sample coated with colloidal graphite to improve emissivity is mounted in a graphite holder which is sited inside a graphite susceptor. A lid having a hole with the same diameter as the sample, serves to cut off the laser beam excess. The susceptor is located inside an induction coil positioned in a vacuum chamber/pressure vessel, which permits measurements over the temperature range $20-2750{ }^{\circ} \mathrm{C}$ either in vacuum or an inert atmosphere such as argon, nitrogen or helium. The temperature of the sample can be monitored either by means of a thermocouple or an optical pyrometer.

Radiation from the rear face of the sample is collected via a lens and a mirror system, and transmitted to the detector assembly external to the vacuum chamber by an optical system. The radiation detector used is a InSb detector, sensitive to 5.5 $\mu \mathrm{m}$ and having a response time of $1.5 \mu \mathrm{s}$. The detector output 
signal is then amplified by means of a commercially available amplifier. The amplified signal is then recorded and processed by a computer via an analog-to-digital converter using a software specially written for this purpose. The schematic diagram of the UMIST apparatus is shown in Fig. 1.

\section{EXPERIMENTAL RESULTS}

Thermal diffusivity measurements corrected for heat losses were carried out from $100{ }^{\circ} \mathrm{C}$ up to approximately $1200{ }^{\circ} \mathrm{C}$. Fig. 2 shows results obtained during the heating branch for all samples. In Fig. 3 thermal diffusivity as a function of temperature is plotted during heating and cooling cycles for sample A1450, and Figs. 4 and 5 show the experimental results of dilatometry for the same sample A1450. X-ray diffraction analysis showed crsitobalite as the majority phase in sample A1450, and free quartz was also detected in samples B1200 and B1400.

As it was pointed out in the experimental procedure, this investigation focused the behaviour of quartz $\alpha \Leftarrow \Rightarrow \beta$ transition contained in a calcined kaolinitic clay $\left(1200 / 1400{ }^{\circ} \mathrm{C}\right)$, as well as that of cristobalite contained in a silica brick for coke oven. In this manner the results and discussion will be devoted to each case separately.

\section{Thermal diffusivity behaviour of the clay}

As shown in Fig. 2 the thermal diffusivity behaviour of the clay material previously fired at $1200{ }^{\circ} \mathrm{C}$ and $1400{ }^{\circ} \mathrm{C}$, is initially dependent on the specimens degree of densification. Then, the thermal diffusivity values for the denser specimen turn out to be $40 \%$ higher for the whole range of temperature investigated $\left(100{ }^{\circ} \mathrm{C}\right.$ to $\left.1200{ }^{\circ} \mathrm{C}\right)$ than that of $1200{ }^{\circ} \mathrm{C}$ fired specimen. However, there is a common trend in both curves which occurs in the range from $500{ }^{\circ} \mathrm{C}-600{ }^{\circ} \mathrm{C}$. The characteristic feature is a steep increase on the thermal diffusivity as a function of temperature, which closely matches the dilatometric behaviour of $\alpha \Leftarrow \beta$ quartz transition at $573{ }^{\circ} \mathrm{C}$. Indeed, X-ray diffraction of the fired specimens presented $\alpha$-quartz peaks with higher intensity for the lower fired specimens $\left(1200{ }^{\circ} \mathrm{C}\right)$. In addition, the raw clay had approximately $22 \mathrm{wt} \%$ quartz. Another aspect to notice is that the steep increase in the $500{ }^{\circ} \mathrm{C}-600{ }^{\circ} \mathrm{C}$ range is smaller for the $1400^{\circ} \mathrm{C}$ fired specimen, which is coherent to the fact that higher firing temperatures cause a decrease in the quartz content because of its dissolution in the liquid phase formed from the impurities $\left(\mathrm{K}_{2} \mathrm{O}, \mathrm{Na}_{2} \mathrm{O}, \mathrm{Fe}_{2} \mathrm{O}_{3}, \mathrm{CaO}\right)$ present in the clay.

From Fig. 2 it can be concluded that the thermal diffusivity behaviour of calcined fireclay is dominated by the $\alpha \Leftarrow \Rightarrow \beta$ quartz phase transition $\left(573{ }^{\circ} \mathrm{C}\right)$, wherever this accessory mineral is present.

\section{Thermal diffusivity behaviour of the silica brick}

In Fig. 3 it can be seen the heating and cooling behaviour of cristobalite rich specimen in the $100{ }^{\circ} \mathrm{C}-1200{ }^{\circ} \mathrm{C}$ range.

Similarly to what happened to the quartz containing fired clay specimens, there is a sudden increase in the thermal diffusivity in a different temperature range $\left(200^{\circ} \mathrm{C}-300{ }^{\circ} \mathrm{C}\right)$ which is characteristic of the $\alpha \Leftarrow \Rightarrow \beta$ cristobalite phase $\left(220^{\circ} \mathrm{C}\right)$.

The cooling part of the plot indicates that the thermal diffusivity values are bigger than the heating part. However, upon cooling in the range of $\beta \Leftrightarrow \Rightarrow \alpha$ cristobalite transition (220 $\left.{ }^{\circ} \mathrm{C}\right)$, the property decreases to that value of the beginning of the cycle.

Figs. 4 and 5 demonstrate that the dilatometric behaviour parallels the thermal diffusivity behaviour, and where the thermal expansion coefficient is largest, so is the thermal diffusivity value.

\section{DISCUSSION}

The observed behaviour in Figs. 2 to 5 of the thermal diffusivity of quartz and cristobalite as a function of temperature, despite its apparently simple origin, is of a complex explanation.

In order to explain it, one has to formulate the following hypotheses:

1- Considering that the investigated specimens of quartz and cristobalite have already been submitted to high temperatures, it is reasonable to assume that the individual grains are microcracked. Besides, crystallographically the $\alpha$ form has a less symmetrical arrangement of the $\mathrm{SiO}_{2}$ tetrahedral, despite the high density and volumetric heat capacity. The lower symmetry implies a lower phonon mean free path. The higher density and heat capacity results in a lower thermal diffusivity value as shown by equation A. When the bulk density of the specimens (in which the phases are immersed) is also taken into consideration, the behaviour of lower values for thermal diffusivity at lower temperatures generated by specimen microstructure can be explained.

2- Upon heating at temperatures higher than the respective $\alpha \Leftarrow \Rightarrow \beta$ transitions, the arrangements of $\mathrm{SiO}_{2}$ tetrahedral of quartz and cristobalite acquire a more symmetrical disposition (increase in phonon mean free path), and for a macro scale the microcracks inside the grains may experience some kind of healing, due to the thermal expansion of the phase. As a consequence, the thermal diffusivity increases abruptly, and for temperatures larger than $900{ }^{\circ} \mathrm{C}$ the contribution of radiation heat transfer to the thermal diffusivity is evident.

3- Upon cooling, the thermal diffusivity does not follow the heating path backwards, because the microcracks are healed and the hysteresis is regenerated when they reopen at the $\beta \Leftrightarrow \alpha$ temperature crossing. However, as already shown [10], after several cycles (heating/cooling), cooling path follows closely the heating path. This indicates that it depends on how stable is the microstructure (mosaic structure).

\section{CONCLUSIONS}

From Figs. 2 to 5 it can be concluded that the displacive transformations occurring during the low to high temperature forms of $\mathrm{SiO}_{2}$ in higher polymorphs quartz or cristobalite, affect not only the thermal expansion behaviour but also the thermal diffusivity behaviour, and by consequence the thermal conductivity. 
The high temperature forms having high thermal diffusivities are less prone to suffer effects of thermal shock and they are able to be subjected to higher heating path without creating deleterious thermal stresses.

\section{ACKNOWLEDGEMENTS}

The authors acknowledge CNPq (Proc. 300186/89-4 and 52014/95-5) for financial support.

\section{REFERENCES}

[1] G. H. Geiger, D. R. Poirier, "Transport Phenomena", Addison-Wesley Publishing Company, Massachusetts, (1980). [2] W. D. Kingery, H. K. Bowen, D. R. Uhlmann, "Introduction to Ceramics", John Wiley \& Sons, New York (1976).

[3] E. W. Brindley, M. Nakahira, J. Am. Ceram. Soc. 42, 311 (1959) 314.

[4] D. P. H. Hasselman, L. F. Johnson, L. D. Bentsen, R. Syed, H. L. Lee, M. V. Swain, Am. Ceram. Soc. Bull. 66, 5 (1987) 799.

[5] G. E. Youngblood, R. W. Rice, R. P. Ingel, J. Am. Ceram. Soc. 71, 4 (1988) 255.

[6] W. J. Parker, R. J. Jenkins, C. P. Butler, G. L. Abbot, J. Appl. Phys. 32, 9 (1961) 1679.

[7] R. Taylor, R., J. Phys. Sci. Instrum. 13 (1980) 1193.

[8] L. M. Clark, R. E. Taylor, J. Appl. Phys. 46 (1975) 714.

[9] D. Cowan, J. Appl. Phys. 34, 4 (1963) 926.

[10] W. N. dos Santos, J. B. Baldo, R. Taylor, Mat. Res. Bull. 35 (2000) 2091.

(Rec. 05/08/02, Ac. 09/09/02) 